\title{
Menilai Dampak Perpustakaan Menggunakan ISO 16439:2014
}

\author{
Muhammad Bahrudin ${ }^{2}$ \\ ${ }^{2}$ Badan Standardisasi Nasional (BSN) \\ Email: m.ambar@live.com
}

\begin{abstract}
Abstrak
Isu terkait cara mengukur atau melakukan penilaian dampak perpustakaan belum banyak dibicarakan di Indonesia. Selama ini perpustakaan berfokus pada bagaimana mengukur kinerjanya dalam berbagai aspek dan penyediaan data statistik yang dilakukan dengan berbagai alat/metode/pendekatan, diantaranya SNI ISO 11620:2014 tentang indikator kinerja perpustakaan dan SNI ISO 2789:2013 tentang statistik perpustakaan. Makalah ini bertujuan untuk memperkenalkan salah satu standar yang dapat digunakan dalam penilaian dampak perpustakaan yaitu ISO 16439-2014, Information and documentation - Methods and procedures for assessing the impact of libraries. Makalah ini merupakan review paper dan metode yang digunakan dalam penulisannya adalah tinjauan umum (general review) yaitu dengan cara memberikan gambaran umum tentang subjek tertentu dengan memeriksa kajian yang telah diterbitkan sebelumnya tentang subjek tersebut. Makalah ini meringkas beberapa metode yang dijelaskan dalam ISO 16439 dan wawasan baru terkait implementasi penilaian dampak perpustakaan berdasarkan standar tersebut. Berdasarkan hasil tinjauan, standar ini secara komprehensif menjelaskan berbagai metode untuk menilai dampak perpustakaan terhadap individu, institusi atau komunitas perpustakaan, dan sosial yang telah digunakan di seluruh dunia oleh berbagai jenis perpustakaan dengan berbagai skala. Standar ini juga menyediakan cara untuk menentukan pilihan metode yang tepat sesuai dengan tujuan penilaian dampak yang ingin dicapai oleh suatu perpustakaan, ruang lingkup, dan sumber daya yang tersedia.
\end{abstract}

Kata Kunci: penilaian perpustakaan; pengukuran dampak; dampak perpustakaan; ISO 16439

\begin{abstract}
Issues on measuring or assessing library impact have not been widely discussed in Indonesia. So far, many libraries have only focused on how to measure its performance in various aspects and the provision of statistical data conducted with various tools / methods / approaches, including SNI ISO 11620:2014 on library performance indicators and SNI ISO 2789:2013 on library statistics. This paper aims to introduce one of the standards that can be used in library impact assessment, ISO 16439-2014, Information and documentation - Methods and procedures for assessing the impact of libraries. This paper is a review paper and the method used in its writing is a general review that is providing an overview of a particular subject by examining previously published studies on the subject. This paper summarizes some of the methods described in ISO 16439 and new insights related to the implementation of library impact assessments based on these standards. Based on the results of the review, this standard comprehensively describes various methods for assessing the impact of libraries on individuals, institutions or library communities, and social that have been used around the world by various types of libraries at various scales. It also provides a way to determine the right method choices according to the impact assessment objectives that a library want to achieve, scope, and resources.
\end{abstract}

Keywords: library assessment; impact measurement; library impact; libraries; ISO 16439

${ }^{1}$ Makalah pernah dipresentasikan pada acara "Webinar dan Knowledge Sharing Kepustakawanan II Tahun 2020 dengan tema Manajemen dan Akuntabilitas Perpustakaan Berbasis Standar" yang diselenggarakan oleh Forum Perpustakaan LPNK Ristek bekerja sama dengan Badan Standardisasi Nasional, Jakarta - 15 Desember 2020 


\section{Pendahuluan}

Sejauh ini, perpustakaan telah berupaya mengukur kinerjanya melalui sumber daya yang tersedia di dalam layanan. Kemudian dari berbagai evaluasi, perpustakaan juga tidak sekedar mengukur efektivitas layanannya tetapi juga meluas ke arah pengukuran kepuasan pengguna. Aktivitas pengukuran kinerja yang menghasilkan hasil analisis data dan statistik tersebut selama ini dirasa cukup sebagai bahan laporan penyelenggaraan manajemen perpustakaan. Namun demikian, data dan statistik yang tersedia selama ini masih belum dapat menjawab ketika muncul pertanyaan mendasar seperti "apa dampak perpustakaan bagi individu atau komunitas?". Semestinya, hari ini baik itu pustakawan maupun akademisi di bidang perpustakaan dan informasi, utamanya di Indonesia, mulai mengembangkan cara-cara atau metode-metode yang dapat digunakan untuk mengukur dampak dari layanan perpustakaan.

Perlu dipahami bahwa di Indonesia isu terkait cara mengukur atau melakukan penilaian dampak perpustakaan belum banyak dibicarakan jika dibandingkan dengan isu terkait dampak perpustakaan itu sendiri. Apalagi jika isunya dipersempit lagi di lingkup perpustakaan khusus. Sebut saja beberapa poin yang kerap dijadikan tujuan strategis suatu institusi perpustakaan seperti penguatan budaya literasi, peningkatan inovasi dan kreativitas pengguna, dan sebagainya. Namun demikian, belum banyak landasan teori yang digunakan untuk mengukur target-target capaian tersebut.

Selain itu, menurut Wijayanti (2019), penilaian perpustakaan masih berorientasi pada diri sendiri (inward looking) di mana penilaian berdasar pada asupan (input), misal jumlah dana, jumlah staf, jumlah bahan perpustakaan, luas perpustakaan, jumlah danjenis fasilitas yang disediakan atau luaran (output) seperti jumlah pinjaman, jumlah kunjungan, unduhan, dan transaksi rujukan.. Sementara itu, jika ingin tetap memiliki eksistensi dan relevan dengan konteks zaman dan masyarakat, perpustakaan tentu perlu melihat keluar, bagaimana ia dapat berdampak bagi penggunanya, baik individu maupun komunitas. Jika ditarik ke konteks perpustakaan khusus terutama di lingkungan instansi pemerintah yang saat ini banyak mengalami degradasi atau penurunan status, baik secara fungsi maupun struktur kelembagaan. Degradasi unit kerja perpustakaan di lingkungan instansi pemerintah ini dapat terjadi jika perpustakaan tidak berperan penting, artinya produk perpustakaan yang berupa jasa dan produk lainnya tidak dapat memuaskan pihak manajemen lembaga induknya (Bahrudin, 2019).

Jika sebelumnya terkait penilaian kinerja perpustakaan, di Indonesia melalui Badan Standardisasi Nasional (BSN) telah mengadopsi 2 (dua) standar internasional yaitu SNI ISO 11620:2014, Informasi dan dokumentasi - Indikator kinerja perpustakaan dan SNI ISO 2789:2013, Informasi dan dokumentasi - Statistik perpustakaan. Kedua standar tersebut ditujukan untuk pengukuran dan penyediaan data-data statistik terkait penggunaan sumber daya perpustakaan dalam melakukan layanan.

Sedangkan terkait penilaian dampak perpustakaan, secara internasional pun International Organization for Standardization (ISO) telah menyediakan panduan yaitu ISO 16439:2014, Information and documentation - Methods and procedures for assessing the impact of libraries. Makalah ini akan menyajikan tinjauan umum terhadap ISO 16439, merangkum metode-metode penting yang dijelaskan dalam standar tersebut. Namun demikian, sebagai batasan adalah bahwa tidak semua metode, terutama komponen-komponennya ditinjau secara mendetail pada makalah ini. 


\section{Metode Penulisan}

Makalah ini merupakan review paper. Review paper akan memberikan gambaran umum tentang subjek tertentu dengan memeriksa kajian yang telah diterbitkan sebelumnya tentang subjek tersebut. Metode yang digunakan adalah tinjauan umum atau general review dengan subjek pilihan adalah standar internasional pertama yang tersedia untuk menilai dampak perpustakaan, yaitu ISO 16439:2014.

Review paper ini merangkum metode-metode penting yang dijelaskan dalam standar tersebut, dan juga memberikan referensi untuk pembelajaran lanjutan. Namun demikian, sebagai batasan adalah bahwa tidak semua metode, terutama komponen-komponennya ditinjau secara mendetail pada makalah ini. Review paper yang baik tidak hanya merangkum keadaan pengetahuan terkini di bidang tertentu, tetapi juga mensintesis literatur untuk memberikan wawasan baru dan memajukan bidang penelitian tersebut (Denney \& Tewksbury, 2013; Pautasso, 2013; Torraco, 2005; Van Wee \& Banister, 2016; Webster \& Watson, 2002 dalam Sayer:2018). Review paper ini dapat menjadi titik awal yang berguna untuk proyek penelitian lanjutan terkait subjek "penilaian dampak perpustakaan".

\section{Hasil dan Pembahasan Dampak Perpustakaan}

Dampak perpustakaan bukanlah ilmu pasti dan dianggap sebagai sesuatu yang tidak berwujud (intangible) dan sulit diukur (Creaser, 2018). Lebih lanjut menurut Creaser, saat mengelola kinerja perpustakaan, beberapa istilah berikut digunakan untuk mendeskripsikan elemen dasar dalam aktivitas pengukuran, yaitu;

- Input (masukan), yaitu sumber daya yang disediakan untuk layanan perpustakaan (mis. staf, ruang, finansial)

- Output (luaran), yaitu hasil penggunaan sumber daya untuk aktivitas layanan perpustakaan (mis. peminjaman koleksi, download, kunjungan)

- Outcome (hasil), yaitu dampak yang dihasilkan dari output, dalam kaitannya dengan tujuan dan sasaran layanan perpustakaan (mis. kepuasan pengguna)

- Impact (dampak), yaitu perbedaan yang dihasilkan oleh layanan perpustakaan terhadap individu dan/atau komunitas (mis. peningkatan kompetensi, dampak ekonomi)

- Value (nilai), yaitu kepentingan yang dibawa oleh stakeholder terhadap layanan perpustakaan (mis. kontribusi terhadap budaya)

ISO 16439 mendefinisikan dampak perpustakaan sebagai pengaruh perpustakaan dan layanannya terhadap individu dan/atau komunitas. Lebih lanjut dalam ISO 16439 menyebutkan bahwa outcome tidak sama dengan dampak (impact), tetapi lebih sebagai efek dari output yang terkait dengan tujuan dan sasaran perencanaan perpustakaan (2014). Kemudian dalam ISO 16439 juga dijelaskan bahwa dampak perpustakaan dapat dilihat dari beberapa aspek, diantaranya;

- langsung (immediate), seperti menemukan informasi berguna atau jangka panjang (longterm), seperti peningkatan literasi informasi;

- jangkauan luas (far-reaching), seperti mengubah kehidupan masyarakat atau terbatas (limited), seperti mengubah kemampuan seseorang dalam mencari informasi;

- disengaja (intended), seperti sesuai dengan misi dan tujuan perpustakaan atau tidak disengaja (unintended) yang dapat meningkatkan sikap positif terhadap perpustakaan, seperti pengunjung yang kemungkinan mengalami kontak sosial di perpustakaan; 
- manfaat aktual bagi pengguna, seperti pemanfaatan perpustakaan untuk isu literasi anakanak; dan manfaat potensial bagi pengguna, seperti pelestarian warisan budaya oleh perpustakaan untuk generasi mendatang.

Kontak dengan aktivitas dan layanan perpustakaan dapat menghasilkan dampak yang berbeda baik terhadap individu ataupun komunitas, tergantung dengan pengalaman dan kompetensi mereka. Poll (2012) menyebutkan bahwa dampak perpustakaan setidaknya dapat dibedakan menjadi dampak terhadap individu (impact on indviduals) dan dampak sosial (social impact). Dampak sosial di sini juga termasuk dampak terhadap institusi perpustakaan itu sendiri dan juga komunitas.

Secara spesifik ISO 16439 juga menjelaskan pengaruh dampak perpustakaan yang dibagi menjadi 3 (tiga), yaitu;

a) Dampak pada individu;

Bagi individu, dampak dari kontak terhadap sumber daya dan layanan perpustakaan dapat memberikan pengaruh diantaranya;

- peningkatan keterampilan dan kompetensi;

- perubahan sikap dan perilaku;

- kesuksesan yang lebih baik dalam riset, studi, atau karir; dan

- kesejahteraan individu (well-being).

b) Dampak pada institusi atau komunitas perpustakaan

Setelah memengaruhi individu atau kelompok, cakupan dampak perpustakaan dapat meluas termasuk lembaga atau komunitas perpustakaan (misal lembaga, kementerian, universitas).

Dampak ini meliputi;

- peningkatan prestise dan peringkat institusi;

- visibilitas perpustakaan lebih besar dan positif bagi lembaga atau komunitas;

- peningkatan pendanaan kelembagaan, hibah penelitian, donor

- menarik para peneliti, staf, dan/atau mahasiswa terbaik;

- menarik entitas penelitian lain, sektor privat, NGO, dan sebagainya.

c) Dampak sosial

Dampak sosial perpustakaan dapat merujuk pada pengaruh keberadaan perpustakaan dan layanannya terhadap populasi di masyarakat sekitar atau masyarakat pada umumnya.

Dampak sosial perpustakaan diantaranya adalah sebagai berikut;

- peningkatan inklusi sosial dan kohesi sosial;

- akses terbuka terhadap informasi;

- pendidikan dan pembelajaran sepanjang hayat;

- budaya dan identitas lokal; dan

- peningkatan kesehatan yang lebih baik.

\section{Metode untuk Menilai Dampak Perpustakaan}

Dampak perpustakaan, sebagaimana sifatnya yang tidak berwujud (intangible), tidak dapat diketahui secara langsung, sehingga perlu menggunakan metode yang tepat untuk melakukan penilaian. Proses ini lebih kompleks daripada sekedar menghitung input dan output, serta membutuhkan waktu dan upaya yang lebih besar. Namun demikian, karena semakin besarnya tuntutan para pihak yang 
membutuhkan transparansi dan laporan yang lebih riil mengenai dampak perpustakaan, upaya ini tetap perlu dilakukan.

Makalah ini memaparkan ISO 16439 sebagai metode penilaian dampak perpustakaan yang direkomendasikan dan komprehensif. Standar ini dikembangkan oleh badan standar internasional yaitu ISO (International Organization for Standardization) yang berkantor pusat di Jenewa, Swiss. ISO 16439 dirumuskan oleh ISO/TC 46/SC 8, Quality - Statistics and performance evaluation terutama melalui Working Group 10, Methods and procedures for assessing the impact of libraries, yang melibatkan 17 ahli dari 13 negara.

Standar ini telah diinisiasi sejak tahun 2010 dan setelah melalui proses panjang akhirnya ditetapkan menjadi standar pada tahun 2014. ISO 16439 dikembangakn untuk memenuhi kebutuhan dunia perpustakaan terkait metode yang efektif untuk menilai dampak perpustakaan. Saat ini, ISO 16439:2014 merupakan versi termutakhir standar penilaian dampak perpustakaan. Berdasarkan informasi di website https://www.iso.org/ standar ini telah dikaji ulang (review) dan dikonfirmasi pemberlakuannya pada Oktober 2019.

ISO 16439 memberikan standardisasi istilah dan definisi untuk penilaian dampak perpustakaan. Di dalamnya, banyak muncul terminologi yang terkait bagaimana perpustakaan menilai dampak bagi penggunanya. Selain penilaian dampak, dokumen ini juga menyediakan pedoman bagi perpustakaan untuk menentukan nilai (value) manfaat perpustakaan. Dengan proses panjang dalam pengembangannya, standar ini telah menyelaraskan berbagai metode penilaian dampak yang telah teruji dan terbukti memberikan hasil yang bermakna.

Secara struktur, ISO 16439 terdiri atas 10 (sepuluh) klausul mulai dari ruang lingkup, acuan normatif, istilah dan definisi, definisi dan dampak perpustakaan, dan 5 (lima) klausul yang secara rinci menyajikan metode untuk menilai dampak perpustakaan serta 1 (satu) klausul untuk menilai nilai manfaat ekonomi perpustakaan. Standar ini juga dilengkapi 3 (tiga) annex atau lampiran yaitu; contoh survei, memilih metode, dan penilaian dampak perpustakaan dalam penilaian institusi dan organisasi yang lebih luas.

Terkait ruang lingkup ISO 16439, standar ini mendefinisikan berbagai istilah penilaian dampak perpustakaan dan menentukan metodenya dengan tujuan, diantaranya;

- perencanaan strategis perpustakaan;

- perbandingan dampak perpustakaan dari waktu ke waktu;

- mempromosikan peran dan nilai perpustakaaan untuk aktivitas pembelajaran, pendidikan, budaya, dan sosial ekonomi; dan

- mendukung pengambilan keputusan dan sasaran strategis perpustakaan.

Umumnya, dampak perpustakaan bersifat kualitatif dan manajemen mengalami kesulitan untuk menemukan bukti yang kredibel yang diakui. Mengutip Streatfield (2002 dalam ISO, 2014), buktibukti tersebut dapat dikumpulkan melalui 3 (tiga) cara yaitu; a) bukti yang disimpulkan (inferred evidence) dari data perpustakaan lainnya atau kombinasi dengan data kualitatif; b) bukti yang diminta (solicited evidence), dengan menanyakan kepada pengguna perpustakaan tentang pengalaman mereka; 
dan c) bukti yang diobservasi (observed evidence) dari mempelajari interaksi pengguna dengan aktivitas perpustakaan baik secara langsung maupun tidak langsung.

\section{Bukti yang Disimpulkan (Inferred Evidence)}

Jika selama ini perpustakaan secara rutin mengumpulkan data-data untuk laporan tahunan, pengukuran kinerja dan survei kepuasan pengguna, maka data tersebut dapat digunakan sebagai bukti yang disimpulkan (Klausul 6 ISO 16439) untuk mengidentifikasi aspek-aspek dampak. Sebagai contoh statistik penggunaan dan pengguna perpustakaan, jika diukur dari waktu ke waktu, dapat menunjukkan apakah dan seberapa sering kelompok tertentu mengunjungi perpustakaan, mengakses sumber daya elektronik atau menghadiri berbagai pelatihan literasi informasi. Jika jumlah tersebut semakin meningkat dari waktu ke waktu, hal tersebut mungkin saja menunjukkan nilai atau dampak dari kegiatan itu.

Demikian pula jika di perpustakaan khusus misalnya sedang meneliti bahwa pegawai merasa nyaman melakukan aktivitas pekerjaan di perpustakaan dilihat dari tingkat keterisian kursi yang tinggi oleh kelompok pegawai yang tengah diteliti tersebut. Meskipun demikian, indikator ini belum cukup memberikan bukti mengenai hipotesis dampak, dan harus didukung oleh indikator lain yang lebih kualitatif, seperti disebutkan sebelumnya.

Penggunaan sistem otomasi perpustakaan seperti SliMS dan INLISLITE sebenarnya dapat memfasilitasi manajemen untuk menyimpulkan dampak dari statistik perpustakaan yang dikumpulkan secara teratur. Data-data seperti sirkulasi koleksi, jumlah hit dan visitor website, akses dan download di sumber elektronik dapat berkorelasi positif dengan peningkatan indeks literasi pengguna. Penelitian yang dilakukan oleh Haddow dan Joseph (2010 dalam De Jager, 2017) menggunakan data sirkulasi buku dan log-in ke komputer dan sumber online untuk menunjukkan bahwa penggunaan sumber daya perpustakaan berkorelasi dengan tingkat retensi siswa.

Jika perpustakaan telah menggunakan indikator-indikator kinerja yang tercantum dalam ISO 11620 juga dapat menjadi landasan data untuk menunjukkan dampak. Memang benar bahwa indikator kinerja tersebut digunakan untuk mengevaluasi kualitas layanan dan produk perpustakaan, bukan efek dari layanan dan produk tersebut pada pengguna dan masyarakat. Akantetapi, hasil indikator kinerja ini, terutama data yang dikumpulkan dari waktu ke waktu dapat menunjukkan dampak perpustakaan. Sebagai contoh, jika penggunaan per anggota populasi meningkat (mis. Jumlah pinjaman atau kunjungan perpustakaan per kapita yang semakin tinggi) dapat menunjukkan pada perubahan sikap dan perilaku populasi. Satu indikator saja memang seringkali tidak cukup untuk mengasumsikan dampak. Berikut adalah contoh lain indikator berdasarkan ISO 11620 yang dapat digunakan untuk mengidentifikasi dampak diantaranya;

- jumlah pinjaman per kapita;

- jumlah unduhan per kapita;

- jumlah kunjungan perpustakaan per kapita;

- jumlah keadiran pada acara perpustakaan atau sesi pelatihan per kapita;

- jumlah keterisian tempat di perpustakaan;

- persentase judul yang dibutuhkan dalam koleksi elektronik; dll. 
Selain itu, jika perpustakaan selama ini melakukan survei kepuasan pengguna dengan metode yang konsisten dalam interval waktu yang teratur, data-data hasil survei tersebut dapat digunakan untuk mengidentifikasi dampak. Kepuasan yang tinggi dengan layanan referensi misalnya, dapat menunjukkan bahwa pengguna mendapat informasi berharga dari layanan tersebut. Kepuasan yang tinggi dengan kegiatan pelatihan yang dilakukan perpustakaan dapat menunjukkan bahwa peserta mendapatkan keterampilan baru yang bermanfaat. Studi kasus di Perpustakaan BSN, kepuasan yang tinggi dengan kecepatan atau ketepatan pengiriman layanan dokumen standar secara online menunjukkan bahwa pengguna telah mendapatkan keuntungan dengan menghemat dan tenaga dalam pekerjaan mereka.

\section{Bukti yang Diminta (Solicited Evidence)}

Metode ini terdapat pada Klausul 7 ISO 16439. Metode ini menggunakan berbagai teknik untuk mempertanyakan kepada individu atau kelompok tentang pengelaman mereka dalam menggunakan perpustakaan atau persepsi mereka tentang nilai sumber daya dan layanan perpustakaan. Metode tersebut dapat berupa survei, wawancara, diskusi terpumpun (focus group discussion/FGD), penilaian mandiri (self assessment), dan mengumpulkan bukti anekdotal.

Pertama, survei merupakan instrumen yang paling sering digunakan untuk menentukan dampak perpustakaan secara langsung atau jangka panjang dialami oleh pengguna (ISO, 2014:28). Informasi yang dikumpulkan melalui survei dampak biasanya mencakup penilaian mandiri pengguna atas keterampilan, pengetahuan, dan perilaku mereka. Sebagaimana penjelasan pada metode sebelumnya, hasil survei perlu digabungkan dengan metode lainnya untuk memberikan bukti-bukti yang lebih valid dampak perpustakaan. Secara detail, ISO 16439 memberikan penjelasan detail mengenai struktur dan format survei dampak, jenis pertanyaan, hingga detail konten surveinya.

Kedua, pertanyaan lisan dalam bentuk wawancara dapat dilakukan secara individu atau kelompok (FGD) baik secara tatap muka, telepon atau internet. Metode interaktif ini dapat membahas subjek tertentu secara lebih terperinci. Namun demikian, wawancara ini umumnya lebih memakan waktu sehingga antisipasinya wawancara dapat dilakukan secara berkelompok (FGD) alih-alih individual. Wawancara dapat dilakukan secara terstruktur, tidak terstruktur, maupun semi-terstruktur. Salah satu teknik khusus dalam wawancara adalah CIT (critical incident technique) yang berfokus pada peristiwa dan pengalaman tertentu (ISO, 2014:28).

Ketiga, penilaian mandiri (self-assessment) dapat menjadi metode yang efektif bagi perpustakaan untuk mengidentifikasi dampak, terutama terkait hasil pelatihan pengguna atau layanan referensi. Penilaian ini dapat dilakukan sebelum dan setelah kontak dengan layanan tersebut untuk menunjukkan gap kondisi dan pengaruh sebelum dan setelah menerima layanan. Pada kegiatan pelatihan perpustakaan tentu sering mendengar istilah pre-test dan post-test. Penilaian mandiri ini juga sebaiknya digunakan dengan mengombinasikan dengan metode kualitatif lainnya seperti FGD atau wawancara semi-terstruktur.

Keempat, bukti anekdotal didasarkan pada anekdot atau cerita yang diperoleh secara informal dair pengamatan dan pengalaman pribadi (ISO, 2014:44). Sumber-sumber yang dapat digunakan untuk mengumpulkan bukti anekdotal di perpustakaan diantaranya; a) komentar pengguna, baik dalam bentuk fisik maupun virtual melalui sistem informasi perpustakaan; b) kuesioner, pada beberapa kuesioner 
biasanya terdapat bagian tertentu yang menyediakan kolom untuk jawaban bebas; dan c) wawancara, sebagian besar hasil wawancara berupa teks bebas berupa pendapat atau pengalaman responden maka data tersebut dapat dikumpulkan.

Secara umum, kumpulan anekdot perlu disusun dan dikelompokan ke dalam kategori dampak yang representatif untuk membuat pola dalam data yang terlihat. Setelahnya, karena bukti anekdotal tidak dianggap sahih secara ilmiah, data ini dapat digunakan sebagai sumber hipotesis untuk penyelidikan lebih lanjut dengan dukungan metode lainnya.

\section{Bukti yang Diamati (Observed Evidence)}

Pada Klausul 8 ISO 16439, menyediakan metode untuk mengumpulkan bukti berdasarkan hasil pengamatan perilaku pengguna selama kontak dengan layanan perpustakaan, termasuk pengamatan langsung maupaun pengamatan oleh perangkat teknis. Pendekatan yang termasuk dalam metode ini yaitu; observasi, analisis log, rekaman mandiri (self-recording), dan analisis kutipan (citation analysis).

Terkait analisis log, metode ini dapat menggantikan pengamatan secara langsung untuk melihat penggunaan sumber daya dan layanan elektronik. File log dapat berasal dari berbagai sistem perpustakaan, seperti; katalog daring, basis data, situs web perpustakaan. ISO 16439 menjelaskan bahwa analisis log dapat mengungkapkan detail interaksi pengguna seperti;

- nama domain pengguna;

- tanggal dan waktu transaksi;

- $\quad$ waktu yang dihabiskan untuk pencarian atau kunjungan;

- yang yang dirujuk dan halaman yang dikunjungi;

- $\quad$ kata kunci dalam pencarian;

- jumlah pencarian;

- penggunaan tautan (link);

- jumlah unduhan; dll.

Rekaman mandiri (self-recording) oleh pengguna adalah instrumen penting yang dapat digunakan untuk mengidentifikasi dampak perpustakaan. Pengguna dapat diminta untuk mencatat perilaku mereka dalam pencarian informasi selama periode waktu tertentu untuk melihat apakah perpustakaan memiliki dampak. Sementara itu, analisis kutipan (citation analysis) dapat digunakan untuk menilai dampak perpustakaan terhadap tingkat literasi pengguna. Metode ini bertujuan untuk melihat perubahan perilaku pengutipan setelah periode tertentu penggunaan sumber daya perpustakaan atau setelah mengikuti program pelatihan literasi informasi.

\section{Metode Gabungan (Combining Methods)}

Klausul 9 ISO 16439 menyediakan metode penilaian dampak perpustakaan dengan menggabungkan beberapa metode sekaligus. Pada bagian ini memberikan panduan yang spesifik untuk metode yang dapat digabungkan secara bermakna, bersamaan dengan isu-isu permasalahan yang mungkin muncul. Sederhananya, metode gabungan dapat dilakukan dengan menggunakan data kualitatif dan kuantitif atau menggunakan beberapa metode dengan salah satu jenis data tersebut. 
Penambangan data (data mining) sebagaimana tercantum pada Klausul 5.6.2.3 ISO 16439 juga dianggap sebagai metode campuran, karena dapat menggunakan kumpulan data dari orgaisasi yang berbeda dan metode yang berbeda untuk menganalisisnya. Data kuantitatif perpustakaan dapat dibandingkan dengan data lain dari dalam atau luar perpustakaan. Data tersebut kemudian dianalisis menggunakan perangkat lunak analisis statistik (mis. R, Python, SPSS, dll.) untuk menentukan hubugan dan signifikansinya.

Sebagai contoh sebagaimana tersedia dalam ISO 16439, perpustakaan dapat menilai dampak perpustakaan sebagai tempat (library as place) bagi penggunanya. Di masa pandemi COVID-19, terjadi peningkatan akses jarak jauh terhadap layanan dan sumber daya perpustakaan. Namun demikian, perpustakaan tetap menjadi sangat penting sebagai tempat secara fisik. Atribut perpustakaan yang mencakup fasilitas fisik seperti ruang tunggu, ruang baca, perangkat TI, koleksi, layanan, dan lingkungan mendukung aktivitas belajar, bekerja, pertemuan, dan komunikasi antara pengguna. Selanjutnya, perpustakaan dapat mengumpulkan data kuantitaif yang terkait dengan penggunaan layanan dan fasilitas. Hasil data tersebut memang belum menunjukkan alasan mengapa orang mengunjungi perpustakaan atau nilai perpustakaan fisik bagi individu maupun kelompok sehingga diperlukan penggabungan metode untuk menyajikan data statistik dan pemahaman yang lebih komprehensif mengenai dampak melalui data kualitatif (lihat Tabel 1.)

Tabel 1. Contoh metode gabungan untuk menilai dampak perpustakaan sebagai tempat (ISO, 2014:55)

\begin{tabular}{|c|c|c|}
\hline Measures & combined with & Measures \\
\hline $\begin{array}{l}\text { Entrance counts or counts of } \\
\text { user places occupancy }\end{array}$ & & $\begin{array}{l}\text { Results from individual interviews on reasons for com- } \\
\text { ing to the library }\end{array}$ \\
\hline $\begin{array}{l}\text { On-site transaction counts (ref- } \\
\text { erence transactions, loans etc.) }\end{array}$ & & $\begin{array}{l}\text { Findings from focus groups on value of the library's } \\
\text { services }\end{array}$ \\
\hline Attendances at user training & & Self-assessment of gains in competencies and skills \\
\hline $\begin{array}{l}\text { Attendances at special events or } \\
\text { programmes }\end{array}$ & & $\begin{array}{l}\text { Observation of behaviour in situ or as result of the } \\
\text { attendance }\end{array}$ \\
\hline
\end{tabular}

Berdasarkan tabel di atas menunjukkan bahwa secara kuantitaif perpustakaan menyediakan data terkait penggunaan sarana dan prasarananya. Sedangkan data kualitatif digunakan untuk mengidentifikasi alasan pengguna datang ke perpustakaan. Kedua data tersebut digabungkan sehingga menghasilkan analisis yang lebih komprehensif untuk menunjukkan dampak perpustakaan sebagai tempat secara fisik bagi penggunanya.

\section{Menilai Dampak Ekonomi Perpustakaan}

Klausul 10 ISO 16439 menyajikan panduan untuk menilai nilai ekonomi (economic value) perpustakaan. Hal ini tentu bukan masalah sederhana karena perpustakaan diharapkan dapat menghitung anggaran yang digunakan dengan menunjukkan dampak atau nilai ekonomi dari aktivitasnya. Sebagai contoh yang dilakukan oleh Perpustakaan Nasional RI, data kurun 2018-2019 menunjukkan bahwa komparasi dari total biaya program perpustakaan terhadap nilai monetisasi benefit/manfaat program tersebut mendapatkan cost-benefit ratio (CBR) sebesar 1:1,2 yang bermakna bahwa perpustakaan memberikan nilai ekonomis yang lebih besar terhadap terhadap kehidupan masyarakat dibandingkan dengan biaya yang dikeluarkan (Santoso, 2020). 
Semua jenis perpustakaan memiliki tuntutan yang sama untuk menyediakan akuntabilitas yang tinggi karena merupakan bagian dari lembaga atau komunitasnya sehingga harus relevan dan terintegrasi dengan misi dan tujuan induknya. Pada bagian ini, memberikan gambaran detail bahwa jika perpustakaan membutuhkan argumen yang kuat untuk akuntabilitas anggarannya, maka menghitung nilai layanannya dalam terminologi finansial menjadi sesuatu yang penting. Manajemen perpustakaan sebaiknya dapat menunjukkan bahwa anggaran yang tersedia telah digunakan dan dikonversi menjadi layanan yang berharga, bermanfaat bagi pengguna dan mendukung lembaga yang mendanai.

Menilai dampak ekonomi perpustakaan dapat ditinjau dari dalam 2 (dua) perspektif, yaitu;

a) Nilai manfaat perpustakaan dalam terminologi moneter

Dalam hal ini, manfaat yang dihasilkan oleh layanan perpustakaan dihitung dalam bentuk uang dan hasilnya dapat dibandingkan dengan investasi lembaga dan perpustakaan pada layanan tersebut. Metode ini dapat dihitung misalnya dengan cara;

- menghitung biaya pengganti jika suatu layanan perpustakaan tersedia di pasaran;

- menghitung biaya waktu, yang dikonversi dengan gaji pengguna sesuai waktu yang dihabiskan ketika memanfaatkan layanan perpustakaan;

- penilaian kontingensi, yaitu meminta pengguna untuk memperkirakan nilai moneter perpustakaan atau layanan tertentu bagi diri mereka sendiri atau masyarakat;

- cost-benefit analysis (analisis biaya-manfaat), yaitu upaya untuk mengukur manfaat suatu proyek atau lembaga dalam terminologi moneter dan membandingkan dengan biaya yang dikeluarkan sehingga menghasilkan cost-benefit ratio (rasio biaya-manfaat).

b) Dampak ekonomi perpustakaan

ISO 16439 mendefinisikan metode ini sebagai efek dari suatu kebijakan, program, proyek, kegiatan atau peristiwa terhadap perekonomian suatu wilayah. Biasanya diukur dalam pertumbuhan ekonomi, perubahan terkait pekerjaan dan pendapatan. Manajemen dapat mengidentifikasi pengaruh positif perpustakaan baik secara langsung maupun tidak langsung terhadap kehidupan ekonomi masyarakat, wilayah, atau bahkan ekonomi nasional.

\section{Pemilihan Metode Penilaian Dampak Perpustakaan}

Mengukur dampak perpustakaan adalah aktivitas penelitian, sehingga alternatif pilihan metode sangat bergantung pada pertanyaan yang ingin dijawab. Aspek pemilihan metode ini tercantum dalam Annex B (Lampiran B) ISO 16439. Penelitian dampak perpustakaan sangat perlu dimulai dengan menentukan area mana dari dampak yang akan diteliti, dan jenis data apa saja yang diperlukan untuk mengidentifikasi dampak tersebut. Selain itu, metode dan ruang lingkup penelitian juga akan bergantung pada sumber daya dan keahlian yang tersedia untuk pelaksanaannya.

ISO 16439 menunjukkan bahwa pilihan satu atau lebih metode untuk menilai dampak perpustakaan akan tergantung pada sejumlah faktor utama, diantaranya;

a) Subjek dan tujuan penelitian (mis. dampak jangka panjang atau jangka pendek; dampak umum perpustakaan atau dampak spesifik dari suatu layanan perpustakaan);

b) Populasi yang akan disurvei (mis. total populasi komunitas; pegawai usia 25-54 tahun; mahasiswa pascasarjana, dll.);

c) Audiens yang dituju, bahwa selain perpustakaan itu sendiri, juga ada pengguna, lembaga pendanaan, regulator, media, dan masyarakat umum; 
d) Keahlian dan sumber daya yang tersedia;

e) Faktor eksternal lainnya (mis. perlunya kolaborasi dengan pihak lain di luar perpustakaan, persyaratan izin penggunaan data pribadi pengguna, dll.)

Tabel 2 dan Tabel 3 berikut adalah contoh pemilihan metode berdasarkan jenis dampak berdasarkan ISO 16439.

Tabel 2. Contoh pemilihan metode berdasarkan jenis dampak

\begin{tabular}{|c|l|l|}
\hline No & \multicolumn{1}{|c|}{ Jenis dampak } & \multicolumn{1}{|c|}{ Metode yang dapat digunakan } \\
\hline 1 & $\begin{array}{l}\text { Perubahan keterampilan } \\
\text { dan kompetensi }\end{array}$ & $\begin{array}{l}\text { Observasi, analisis log, tes, wawancara, self- } \\
\text { assessment, }\end{array}$ \\
\hline 2 & $\begin{array}{l}\text { Perubahan sikap dan } \\
\text { perilaku }\end{array}$ & $\begin{array}{l}\text { Survei, wawancara, data anekdotal, self-recording, } \\
\text { statistik penggunaan perpustakaan, observasi }\end{array}$ \\
\hline 3 & $\begin{array}{l}\text { Peningkatan keberhasilan } \\
\text { pengguna dalam studi, } \\
\text { riset, atau karier }\end{array}$ & $\begin{array}{l}\text { Membandingkan penggunaan perpustakaan oleh } \\
\text { individu dengan data keberhasilan pengguna; } \\
\text { wawancara }\end{array}$ \\
\hline 4 & Dampak sosial & Survei, wawancara, FGD \\
\hline
\end{tabular}

Tabel 3. Contoh pemilihan metode berdasarkan jenis layanan

\begin{tabular}{|c|l|l|}
\hline No & \multicolumn{1}{|c|}{ Jenis layanan } & \multicolumn{1}{c|}{ Metode yang dapat digunakan } \\
\hline 1 & Layanan referensi & Observasi, analisis log, wawancara, self-assessment \\
\hline 2 & Literasi informasi & Tes, self-assessment, kuesioner, analisis kutipan \\
\hline 3 & Layanan akses internet & Wawancara, survei, data anekdotal \\
\hline 4 & Layanan e-resources & $\begin{array}{l}\text { Statistik penggunaan, survei, wawancara, FGD, } \\
\text { analisis log }\end{array}$ \\
\hline
\end{tabular}

\section{Penutup}

Perpustakaan, apapun jenis dan skalanya, memiliki peran strategis di bagi individu maupun komunitas dan lembaga induknya, memberikan fasilitas yang permanen terhadap pengetahuan, menyajikan keterkinian dalam informasi dan referensi ilmiah. Namun demikian, perpustakaan perlu untuk memberikan bukti otentik dan akuntabel mengenai dampaknya baik terhadap individu maupun komunitas dan juga nilai manfaat ekonomi dari layanan yang diberikan. ISO 16439 dapat digunakan sebagai panduan untuk melakukan penilaian dampak perpustakaan yang komprehensif.

Dalam melakukan penilaian dampak perpustakaan, beberapa langkah berikut akan sangat membantu dengan merinci proses-proses sistematis dalam komponen penilaian. Pertama, tentukan bidang layanan yang ingin diidentifikasi dampaknya, sebagai contoh fokus pada layanan referensi, atau layanan e-resources, atau lebih umum seperti terkait penyediaan sumber daya perpustakaan. Kedua, fokus pada dampak yang diharapkan dari bidang layanan tersebut, misal pada layanan literasi informasi, dampak yang diharapkan adalah peningkatan keterampilan literasi informasi. 
Ketiga, tentukan parameter atau bukti-bukti yang menunjukkan bahwa dampak yang diharapkan telah tercapai, misal; peningkatan keterampilan literasi informasi ditunjukkan dengan penggunaan sumber informasi yang lebih akurat, penggunaan referensi yang lebih baik, sitasi yang tepat dan sebagainya. Keempat, identifikasi dan tentukan langkah untuk mendapatkan bukti-bukti tersebut, dan identifikasi pula di mana data-data tersebut dapat diperoleh. Pada tahap inilah, langkah-langkah dan metode ISO 16439 dapat digunakan dalam proses penilaian dampak.

\section{Daftar Pustaka}

Badan Standardisasi Nasional. (2020). SNI ISO 11620:2014, Informasi dan dokumentasi - Indikator kinerja perpustakaan. Jakarta: BSN.

Badan Standardisasi Nasional. (2020). SNI ISO 2789:2013, Informasi dan dokumentasi - Statistik perpustakaan. Jakarta: BSN.

Bahrudin, M. (2019, April). Membangun Perpustakaan Khusus yang Adaptif dan Responsif terhadap Dinamika Lembaga Induk: Best Practices di Perpustakaan BSN. Researchgate. https://www.researchgate.net/publication/349703242_Membangun_Perpustakaan_Khusus_yang _Adaptif_dan_Responsif_terhadap_Dinamika_Lembaga_Induk_Best_Practices_di_Perpustakaa n_BSN

Creaser, C. (2018). Assessing the impact of libraries - the role of ISO 16439. Information and Learning Science, 119(1/2), 87-93. https://doi.org/10.1108/ILS-05-2017-0037

De Jager, K. (2015). Using a new ISO standard to measure the impact of the Lyon Declaration. IFLA WLIC 2015 (pp. 1-8). Cape Town: IFLA.

De Jager, K. (2017). Approaches to impact evaluation in academic libraries: A review of a new ISO standard. IFLA Journal, 1-6. doi:10.1177/0340035217696321

International Organization for Standardization. (2014). ISO 16439:2014, Information and documentation - Methods and procedures for assessing the impact of libraries. Geneva: ISO.

Poll, R. (2012). Can we quantify the library's influence? Creating an ISO standard for impact assessment. Performance Measurement and Metrics, 13(2), 121-130. doi:10.1108/14678041211241332

Santoso, J. (2020, December 15). Akuntabilitas perpustakaan dari aspek kinerja dan dampak pada masyarakat. Jakarta: Perpustakaan Nasional RI.

Sayer, E. J. (2018). The anatomy of an excellent review paper. Functional Ecology, 32(10), 2275-2475. https://doi.org/10.1111/1365-2435.13207

Wijayanti, L. (2019). ISO 16439:2014 sebagai alat manajemen untuk meningkatkan peran perpustakaan dalam mengembangkan kapasitas pemustaka. SidePlayer. https://slideplayer.com/slide/14801135/ 